\title{
Trends in Central Bank Transparency
}

\author{
Georgios Oikonomou, Eleftherios Spyromitros \\ Department of Economics, Democritus University of Thrace, Komotini, Greece \\ Email: goikonomou4@gmail.com, espyromi@econ.duth.gr
}

How to cite this paper: Oikonomou, G. and Spyromitros, E. (2017) Trends in Central Bank Transparency. Theoretical Economics Letters, 7, 2089-2103.

https://doi.org/10.4236/tel.2017.77142

Received: September 21, 2017

Accepted: December 5, 2017

Published: December 8, 2017

Copyright $\odot 2017$ by authors and Scientific Research Publishing Inc. This work is licensed under the Creative Commons Attribution International License (CC BY 4.0).

http://creativecommons.org/licenses/by/4.0/

\begin{abstract}
In this paper we have updated Central Bank Transparency Index from 2011 to 2016, following the methodology of Eijffinger and Geraats (2006) [1]. Then, we break down the index's aspects and we analyze which are more likely to be changed through time. This, in respect to the annual data we have collected, makes clearer how the recent financial crisis has affected the Central Banks' transparency trend and offers interesting insights for monetary policy transmission. Also, we divided the countries into developed, emerging and frontiers, as there is difference in their indexes changes, probably related to their economic and financial development.
\end{abstract}

\section{Keywords}

Central Banks, Monetary Policy Transparency

\section{Introduction}

The new paradigm in monetary policy is that Central Banks have to be transparent as well as independent. The communication of monetary policy actions and projections about important macroeconomic and financial variables to the public is crucial for the effectiveness of monetary policy. There is an important strand of the literature highlighting the beneficial effects of increased transparency on the transmission mechanism of monetary policy to the real economy [2] [3]. Additionally, the benefit of Central Bank transparency on macroeconomic and financial outcomes is also highlighted by the existing literature [4]-[11].

The objective of this study is twofold: Firstly, we update the index of Central Bank transparency for 34 countries over the period from 2011 to 2016, following the methodology of Eijffinger and Geraats [1] Secondly, we provide evidence of the evolution of each aspect of Central Bank transparency in our effort to inves- 
tigate which aspects seem to be more important and progressing in the post-crisis period.

An important result of the crisis is the recessionary effects for the economies. However, Central Banks that might have multiple objectives could probably decide to embrace secrecy in order to obtain better results in terms of lower unemployment. On the other hand, more opaque monetary policies may negatively affect the credibility of Central Banks, with severe consequences for the effectiveness of monetary policies. Moreover, there is always enough space to improve transparency, especially for emerging and frontier economies that exhibit relatively low levels of transparency. In such a context, the investigation of the evolution of transparency as a whole as well as the progress of each aspect is of outmost interest.

The remainder of the paper is structured as follows. Section 2 describes the methodology employed to update the index of transparency. In Section 3 we present the index of transparency for the period of investigation. In Section 4, we present separately each aspect of transparency while highlighting the trend. We conclude in the last section.

\section{Methodology}

The transparency index is based on the methodology developed by Eijffinger and Geraats [1] and the aspects they proposed. Although there are several other studies measuring Central Bank transparency, Eijffinger and Geraats promote the most accurate measure of Central Bank transparency as they distinguish its different aspects such as political, economic, procedural, policy and operational transparency ${ }^{1}$. This makes it easier to predict which aspect is more likely to change over time.

All data were drawn from Central Banks' websites, from their publications, quarterly and annual reports and committees meetings' transcripts. Then we asked from Central Banks to judge our completed questionnaires and either agree or disagree, by justifying their proposals. Except for the final valuation, we have chosen to break down the index and see which aspect of transparency is more respected by these Central Banks.

The countries are divided into groups of developed (Canada, USA, Australia, New Zealand, Hong Kong, Japan, Singapore, Israel, Denmark, Iceland, Norway, Sweden, UK and Switzerland), emerging (Egypt, South Africa, Mexico, Chile, Korea, India, Indonesia, Malaysia, Philippines, Thailand, Saudi Arabia, Turkey, Hungary and Russia) and frontier countries (Jamaica, Argentina, Jordan, Romania, Ukraine, Croatia), as proposed by the Morgan Stanley's Index for countries classification. We have individually added the ECB as it represents a group of developed and emerging countries.

${ }^{1}$ There are several studies that produce an index of Central Bank transparency. See, among others, Fry et al. [12], Siklos [13] [14], Crowe and Meade [15], Papadamou [16] and Dincer and Eichengreen [17]. 


\section{Central Bank Transparency Index}

In Table 1 we present Central Bank transparency indexes from 15 developed countries, 14 emerging countries and 6 frontier countries, as divided by the MSCI Index, also including the European Central Bank, over the period 2011-2016. All of these countries are main contributors to the world GDP and their policies play major role to other countries' policies.

The most transparent Central Banks are from Sweden, Hungary, Japan, Iceland, UK, Australia, New Zealand and the ECB, while the least transparent are Saudi Arabia, Jordan and Singapore. We observe that Central Banks such as Switzerland and the ECB have substantially increased their levels of transparency, while there are other Central Banks including the FED and Australia, which remain almost unchanged over the period of investigation.

As we can presume from Figure 1 there is a trend of increase in Central Bank transparency, which has also been indicated by Dincer and Eichengreen [17]. On average, the transparency levels of developed countries rose from 11.14 to 11.57 during the investigated period, while emerging countries' transparency slightly increased from 8.43 to 8.79 and frontiers showed a greater increase from 6 to 7.33.

All categories of countries, though, have in common a boom between 2014 and 2016. This happened because all major countries set the priority of keeping price stability in their markets. To this extend, a central bank must set an explicit prioritization of quantified inflation level (i.e., an inflation targeting regime) and this automatically gives a boost of +1 to +2 in transparency. All developed countries had already had objectives of their monetary policy and many of them gave the priority to price stability, so they did not gain. Emerging and frontier countries, which had in common no prioritization and quantification of their monetary policy's objectives, earned from valuating their monetary policy. There is a positive relationship between low and stable inflation with high transparency [4] [18], so as Central Banks want to increase their countries' price stability and se-

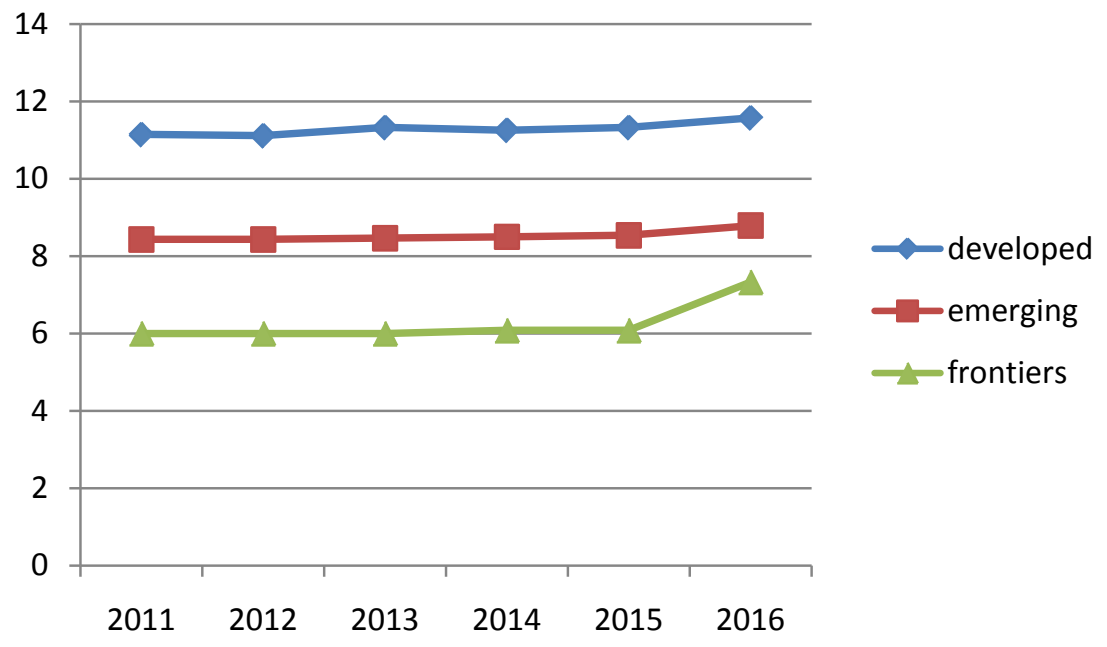

Figure 1. Trends of transparency index. 
Table 1. Transparency index.

\begin{tabular}{|c|c|c|c|c|c|c|}
\hline Country & 2011 & 2012 & 2013 & 2014 & 2015 & 2016 \\
\hline Canada & 14 & 14 & 14 & 13 & 13 & 13 \\
\hline USA & 10.5 & 10.5 & 10.5 & 10.5 & 10.5 & 11.5 \\
\hline Australia & 12 & 12 & 12 & 12 & 12 & 12 \\
\hline New Zealand & 14 & 14 & 14 & 14 & 14 & 14 \\
\hline Hong Kong & 7.5 & 7.5 & 7.5 & 7.5 & 7.5 & 7.5 \\
\hline Japan & 11.5 & 10.5 & 13.5 & 13.5 & 14 & 14 \\
\hline Singapore & 5.5 & 5.5 & 5.5 & 5.5 & 5.5 & 5.5 \\
\hline Israel & 11.5 & 11.5 & 11.5 & 11.5 & 11.5 & 11.5 \\
\hline Denmark & 8 & 8 & 8 & 8 & 8 & 8 \\
\hline Iceland & 13 & 13 & 13 & 13 & 13 & 13.5 \\
\hline Norway & 11 & 11.5 & 11.5 & 11.5 & 11.5 & 11.5 \\
\hline Sweden & 14.5 & 14.5 & 14.5 & 14.5 & 15 & 15 \\
\hline United Kingdom & 13.5 & 13.5 & 13.5 & 13.5 & 13.5 & 13.5 \\
\hline Switzerland & 9.5 & 9.5 & 9.5 & 9.5 & 9.5 & 11.5 \\
\hline Egypt & 7.5 & 7.5 & 7.5 & 7.5 & 8 & 8 \\
\hline South Africa & 8.5 & 8.5 & 8.5 & 8.5 & 8.5 & 8.5 \\
\hline Mexico & 8.5 & 8.5 & 8.5 & 8.5 & 8.5 & 8.5 \\
\hline Chile & 9.5 & 9.5 & 10 & 10 & 10 & 10.5 \\
\hline Korea & 11 & 11 & 11 & 11 & 11 & 11 \\
\hline India & 6.5 & 6.5 & 6.5 & 6.5 & 6.5 & 8.5 \\
\hline Indonesia & 7.5 & 7.5 & 7.5 & 7.5 & 7.5 & 7.5 \\
\hline Malaysia & 7.5 & 7.5 & 7.5 & 7.5 & 7.5 & 7.5 \\
\hline Philippines & 9 & 9 & 9 & 9 & 9 & 9 \\
\hline Thailand & 9 & 9 & 9 & 9 & 9 & 9 \\
\hline Saudi Arabia & 0 & 0 & 0 & 0 & 0 & 0 \\
\hline Turkey & 10 & 10 & 10 & 10 & 10 & 10 \\
\hline Hungary & 14.5 & 14.5 & 14.5 & 14.5 & 14.5 & 14.5 \\
\hline Russia & 9 & 9 & 9 & 9.5 & 9.5 & 10.5 \\
\hline Jamaica & 6.5 & 6.5 & 6.5 & 7 & 7 & 7 \\
\hline Argentina & 7.5 & 7.5 & 7.5 & 7.5 & 7.5 & 7.5 \\
\hline Jordan & 3 & 3 & 3 & 3 & 3 & 3 \\
\hline Romania & 9 & 9 & 9 & 9 & 9 & 9 \\
\hline Ukraine & 5 & 5 & 5 & 5 & 5 & 10 \\
\hline Croatia & 5 & 5 & 5 & 5 & 5 & 7.5 \\
\hline ECB & 11 & 11 & 11 & 11 & 12.5 & 13.5 \\
\hline
\end{tabular}


cure their low levels they must also recognize respect the importance of high transparency as it can secure the policy's effectiveness. While targeting inflation, many central banks decided to become more transparent by increasing other aspects of transparency except for the political aspect, which refers to the quantification of policy primary objectives. For example, the inflation targeting comes with forecasts about inflation [4] and this can add +0.5 to a Central Bank's transparency.

\section{The Evolution of Different Aspects of Central Bank Transparency}

According to the terminology of Geraats [4], there are five aspects of central bank transparency, namely political, economic, procedural, policy and operational.

The political aspect of the transparency index refers to the independence between the Central Banks' administrative council and the Government and whether are there primary objectives of the monetary policy and if they are quantified (see Table 2).

All emerging and frontier countries Central Banks have in common, that they do not sign explicit contracts with the administrative council, but state that there must be no relations with the government and also they have objectives but with no prioritization and quantification. Some frontiers also do not state the non-existence of relations with the government. In contrast, Central Banks in the developed countries had in common the prioritization of the monetary policy objectives and some of them had contracts with the government or quantified the main objective. In 2013, it was observed that the vast majority of the developed countries' Central Banks started to prioritize their policy objectives, quantify them and also sign contracts or state no relations with the government. As it can be seen from Figure 2 there is an upward trend regarding the political aspect of Central Bank transparency.

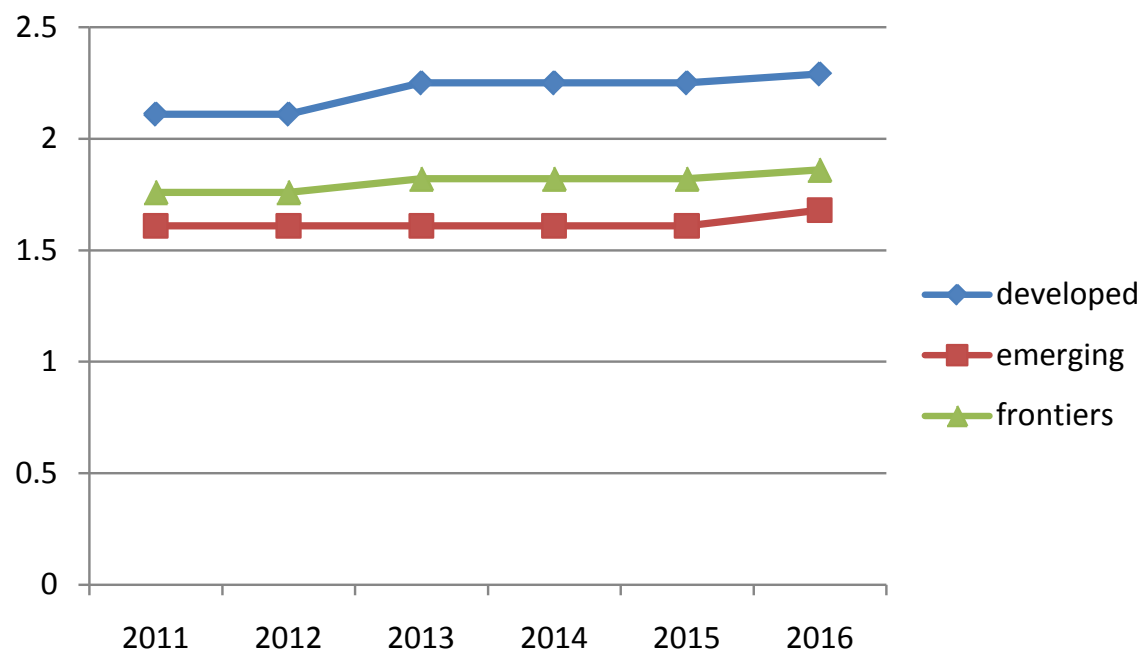

Figure 2. Political aspect trend. 
Table 2. Political aspect.

\begin{tabular}{|c|c|c|c|c|c|c|}
\hline Country & 2011 & 2012 & 2013 & 2014 & 2015 & 2016 \\
\hline Canada & 3 & 3 & 3 & 3 & 3 & 3 \\
\hline USA & 1 & 1 & 1 & 1 & 1 & 1.5 \\
\hline Australia & 2.5 & 2.5 & 2.5 & 2.5 & 2.5 & 2.5 \\
\hline New Zealand & 2.5 & 2.5 & 2.5 & 2.5 & 2.5 & 2.5 \\
\hline Hong Kong & 2.5 & 2.5 & 2.5 & 2.5 & 2.5 & 2.5 \\
\hline Japan & 1 & 1 & 3 & 3 & 3 & 3 \\
\hline Singapore & 1 & 1 & 1 & 1 & 1 & 1 \\
\hline Israel & 2.5 & 2.5 & 2.5 & 2.5 & 2.5 & 2.5 \\
\hline Denmark & 1 & 1 & 1 & 1 & 1 & 1 \\
\hline Iceland & 2 & 2 & 2 & 2 & 2 & 2 \\
\hline Norway & 2 & 2 & 2 & 2 & 2 & 2 \\
\hline Sweden & 3 & 3 & 3 & 3 & 3 & 3 \\
\hline United Kingdom & 2.5 & 2.5 & 2.5 & 2.5 & 2.5 & 2.5 \\
\hline Switzerland & 3 & 3 & 3 & 3 & 3 & 3 \\
\hline Egypt & 1 & 1 & 1 & 1 & 1 & 1 \\
\hline South Africa & 1.5 & 1.5 & 1.5 & 1.5 & 1.5 & 1.5 \\
\hline Mexico & 1 & 1 & 1 & 1 & 1 & 1 \\
\hline Chile & 2.5 & 2.5 & 2.5 & 2.5 & 2.5 & 2.5 \\
\hline Korea & 2 & 2 & 2 & 2 & 2 & 2 \\
\hline India & 1 & 1 & 1 & 1 & 1 & 2 \\
\hline Indonesia & 1.5 & 1.5 & 1.5 & 1.5 & 1.5 & 1.5 \\
\hline Malaysia & 0.5 & 0.5 & 0.5 & 0.5 & 0.5 & 0.5 \\
\hline Philippines & 2.5 & 2.5 & 2.5 & 2.5 & 2.5 & 2.5 \\
\hline Thailand & 2 & 2 & 2 & 2 & 2 & 2 \\
\hline Saudi Arabia & 0 & 0 & 0 & 0 & 0 & 0 \\
\hline Turkey & 2 & 2 & 2 & 2 & 2 & 2 \\
\hline Hungary & 3 & 3 & 3 & 3 & 3 & 3 \\
\hline Russia & 2 & 2 & 2 & 2 & 2 & 2 \\
\hline Jamaica & 1 & 1 & 1 & 1 & 1 & 1 \\
\hline Argentina & 1.5 & 1.5 & 1.5 & 1.5 & 1.5 & 1.5 \\
\hline Jordan & 1 & 1 & 1 & 1 & 1 & 1 \\
\hline Romania & 1.5 & 1.5 & 1.5 & 1.5 & 1.5 & 1.5 \\
\hline Ukraine & 2 & 2 & 2 & 2 & 2 & 2 \\
\hline Croatia & 2 & 2 & 2 & 2 & 2 & 2 \\
\hline $\mathrm{ECB}$ & 3 & 3 & 3 & 3 & 3 & 3 \\
\hline
\end{tabular}


The economic aspect of transparency, presented in Table 3, refers to the disclosure of main economic data, such as GDP, CPI, Money Supply, Employment or Unemployment and Capacity Utilization, the forecasts of the main variables (GDP and CPI) and whether the Central Bank discloses or not the macroeconomic models it uses.

The vast majority of Central Banks publish two to four variables. Most of developed countries' Central Banks publish 4 variables (not Capacity Utilization), while Japan, Iceland and Sweden publish all data mentioned before. Central Banks in frontier countries are more transparent than emerging also at this aspect. Most Central Banks report 3 - 4 variables value at least quarterly and forecasts for GDP and CPI at least annually. Central Banks in emerging countries are less transparent usually publishing $2-3$ variables quarterly and at least annual reports of CPI and GDP expectations, while not disclosing macroeconomic models.

This aspect has the most upward course through time for all 3 categories (see Figure 3). The possible reason for this is that the inflation targeting policy of most Central Banks leads to Inflation Forecasts publishing at least quarterly while being more transparent. Also, inflation targeting leads to adoption of macroeconomic models or model development.

In Table 4 we present the procedural aspect of transparency, which refers to whether the bank releases the framework under which decisions were made, including minutes of explanations, the monetary policy framework and voting records.

Central Banks in developed countries publish minutes of explanations and the framework under which decisions were made. Some of them also publish the voting records from monetary policy committee meetings, and so they reach a 2 to 2.5 with the most transparent central banks having a 2.5 to 3 , as the UK, the USA, Norway, Iceland, Japan, New Zealand and Sweden. Central Banks in emerging countries usually publish some explanations and the framework but

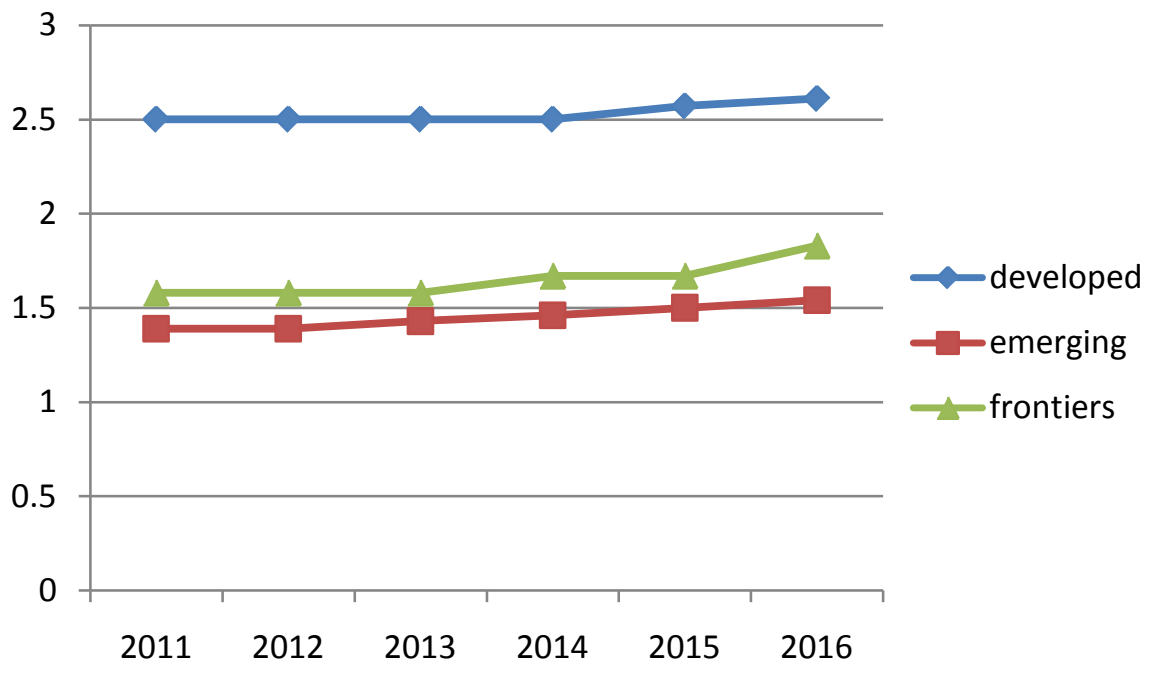

Figure 3. Economic aspect trend. 
Table 3. Economic aspect.

\begin{tabular}{|c|c|c|c|c|c|c|}
\hline Country & 2011 & 2012 & 2013 & 2014 & 2015 & 2016 \\
\hline Canada & 3 & 3 & 3 & 3 & 3 & 3 \\
\hline USA & 2.5 & 2.5 & 2.5 & 2.5 & 2.5 & 2.5 \\
\hline Australia & 2.5 & 2.5 & 2.5 & 2.5 & 2.5 & 2.5 \\
\hline New Zealand & 2.5 & 2.5 & 2.5 & 2.5 & 2.5 & 2.5 \\
\hline Hong Kong & 2 & 2 & 2 & 2 & 2 & 2 \\
\hline Japan & 2.5 & 2.5 & 2.5 & 2.5 & 3 & 3 \\
\hline Singapore & 2 & 2 & 2 & 2 & 2 & 2 \\
\hline Israel & 2.5 & 2.5 & 2.5 & 2.5 & 2.5 & 2.5 \\
\hline Denmark & 2.5 & 2.5 & 2.5 & 2.5 & 2.5 & 2.5 \\
\hline Iceland & 2.5 & 2.5 & 2.5 & 2.5 & 2.5 & 3 \\
\hline Norway & 2.5 & 2.5 & 2.5 & 2.5 & 2.5 & 2.5 \\
\hline Sweden & 2.5 & 2.5 & 2.5 & 2.5 & 3 & 3 \\
\hline United Kingdom & 2.5 & 2.5 & 2.5 & 2.5 & 2.5 & 2.5 \\
\hline Switzerland & 3 & 3 & 3 & 3 & 3 & 3 \\
\hline Egypt & 1 & 1 & 1 & 1 & 1.5 & 1.5 \\
\hline South Africa & 1.5 & 1.5 & 1.5 & 1.5 & 1.5 & 1.5 \\
\hline Mexico & 1.5 & 1.5 & 1.5 & 1.5 & 1.5 & 1.5 \\
\hline Chile & 0 & 0 & 0.5 & 0.5 & 0.5 & 1 \\
\hline Korea & 2 & 2 & 2 & 2 & 2 & 2 \\
\hline India & 0.5 & 0.5 & 0.5 & 0.5 & 0.5 & 0.5 \\
\hline Indonesia & 2 & 2 & 2 & 2 & 2 & 2 \\
\hline Malaysia & 1 & 1 & 1 & 1 & 1 & 1 \\
\hline Philippines & 2 & 2 & 2 & 2 & 2 & 2 \\
\hline Thailand & 2 & 2 & 2 & 2 & 2 & 2 \\
\hline Saudi Arabia & 0 & 0 & 0 & 0 & 0 & 0 \\
\hline Turkey & 1.5 & 1.5 & 1.5 & 1.5 & 1.5 & 1.5 \\
\hline Hungary & 3 & 3 & 3 & 3 & 3 & 3 \\
\hline Russia & 1.5 & 1.5 & 1.5 & 2 & 2 & 2 \\
\hline Jamaica & 1.5 & 1.5 & 1.5 & 2 & 2 & 2 \\
\hline Argentina & 2.5 & 2.5 & 2.5 & 2.5 & 2.5 & 2.5 \\
\hline Jordan & 1 & 1 & 1 & 1 & 1 & 1 \\
\hline Romania & 2 & 2 & 2 & 2 & 2 & 2 \\
\hline Ukraine & 2 & 2 & 2 & 2 & 2 & 2 \\
\hline Croatia & 0.5 & 0.5 & 0.5 & 0.5 & 0.5 & 1.5 \\
\hline $\mathrm{ECB}$ & 2.5 & 2.5 & 2.5 & 2.5 & 2.5 & 2.5 \\
\hline
\end{tabular}


Table 4. Procedural aspect.

\begin{tabular}{|c|c|c|c|c|c|c|}
\hline Country & 2011 & 2012 & 2013 & 2014 & 2015 & 2016 \\
\hline Canada & 2 & 2 & 2 & 2 & 2 & 2 \\
\hline USA & 3 & 3 & 3 & 3 & 3 & 3 \\
\hline Australia & 2 & 2 & 2 & 2 & 2 & 2 \\
\hline New Zealand & 3 & 3 & 3 & 3 & 3 & 3 \\
\hline Hong Kong & 1 & 1 & 1 & 1 & 1 & 1 \\
\hline Japan & 3 & 2 & 3 & 3 & 3 & 3 \\
\hline Singapore & 1.5 & 1.5 & 1.5 & 1.5 & 1.5 & 1.5 \\
\hline Israel & 2 & 2 & 2 & 2 & 2 & 2 \\
\hline Denmark & 1 & 1 & 1 & 1 & 1 & 1 \\
\hline Iceland & 2.5 & 2.5 & 2.5 & 2.5 & 2.5 & 2.5 \\
\hline Norway & 2.5 & 2.5 & 2.5 & 2.5 & 2.5 & 2.5 \\
\hline Sweden & 3 & 3 & 3 & 3 & 3 & 3 \\
\hline United Kingdom & 3 & 3 & 3 & 3 & 3 & 3 \\
\hline Switzerland & 1 & 1 & 1 & 1 & 1 & 1 \\
\hline Egypt & 2 & 2 & 2 & 2 & 2 & 2 \\
\hline South Africa & 2 & 2 & 2 & 2 & 2 & 2 \\
\hline Mexico & 2 & 2 & 2 & 2 & 2 & 2 \\
\hline Chile & 2.5 & 2.5 & 2.5 & 2.5 & 2.5 & 2.5 \\
\hline Korea & 2 & 2 & 2 & 2 & 2 & 2 \\
\hline India & 1.5 & 1.5 & 1.5 & 1.5 & 1.5 & 2.5 \\
\hline Indonesia & 1 & 1 & 1 & 1 & 1 & 1 \\
\hline Malaysia & 2 & 2 & 2 & 2 & 2 & 2 \\
\hline Philippines & 2 & 2 & 2 & 2 & 2 & 2 \\
\hline Thailand & 2 & 2 & 2 & 2 & 2 & 2 \\
\hline Saudi Arabia & 0 & 0 & 0 & 0 & 0 & 0 \\
\hline Turkey & 2 & 2 & 2 & 2 & 2 & 2 \\
\hline Hungary & 3 & 3 & 3 & 3 & 3 & 3 \\
\hline Russia & 2 & 2 & 2 & 2 & 2 & 2 \\
\hline Jamaica & 1 & 1 & 1 & 1 & 1 & 1 \\
\hline Argentina & 1 & 1 & 1 & 1 & 1 & 1 \\
\hline Jordan & 1 & 1 & 1 & 1 & 1 & 1 \\
\hline Romania & 2 & 2 & 2 & 2 & 2 & 2 \\
\hline Ukraine & 1 & 1 & 1 & 1 & 1 & 2 \\
\hline Croatia & 0 & 0 & 0 & 0 & 0 & 1 \\
\hline ECB & 1.5 & 1.5 & 1.5 & 1.5 & 2 & 3 \\
\hline
\end{tabular}


no voting records. In 2016 there was an improvement in this aspect of transparency for Central Banks in both emerging and frontiers. For Central Banks in emerging countries, the increase was explained by the fact that some of them decided to include either voting records or the policy framework. For Central Banks in frontier countries there was almost nothing published describing the monetary policy. The majority of them have their policy decisions published including some explanations but no voting records or policy framework. The increase, noticed in Figure 4, was due to publishing some voting records and some minutes of explanations for the policy decisions.

A presentation of the policy aspect of transparency for all the countries investigated over the period 2011-2016, which refers to the implications of the monetary policy as described by the Central Bank including policy inclination, forward-looking assessment and probable future actions is presented in Table 5.

Almost in all developed countries, Central Banks make predictions about the actions they imply, propose solutions in case of not meeting the targets and almost extensively analyze their policy inclination after every meeting, while publishing them almost immediately after every policy meeting. As it can be seen from Figure 5, there was no increase during the period we studied for the developed countries. In emerging countries, Central Banks have a low level of policy transparency by reaching a median 2.5 at 2016 and a little less during the 5 prior years. This increase was due to Russia's forward-looking assessment. On the other hand, Central Banks in frontier countries are not such transparent as the others, referring to their policy aspect of transparency. Although, a remarkable increase was observed from 2015 to 2016 because some Central Banks had chosen to publish adjustments to the main operating instrument or target on the day of implementation or before that and explanations when their policy decisions were announced.

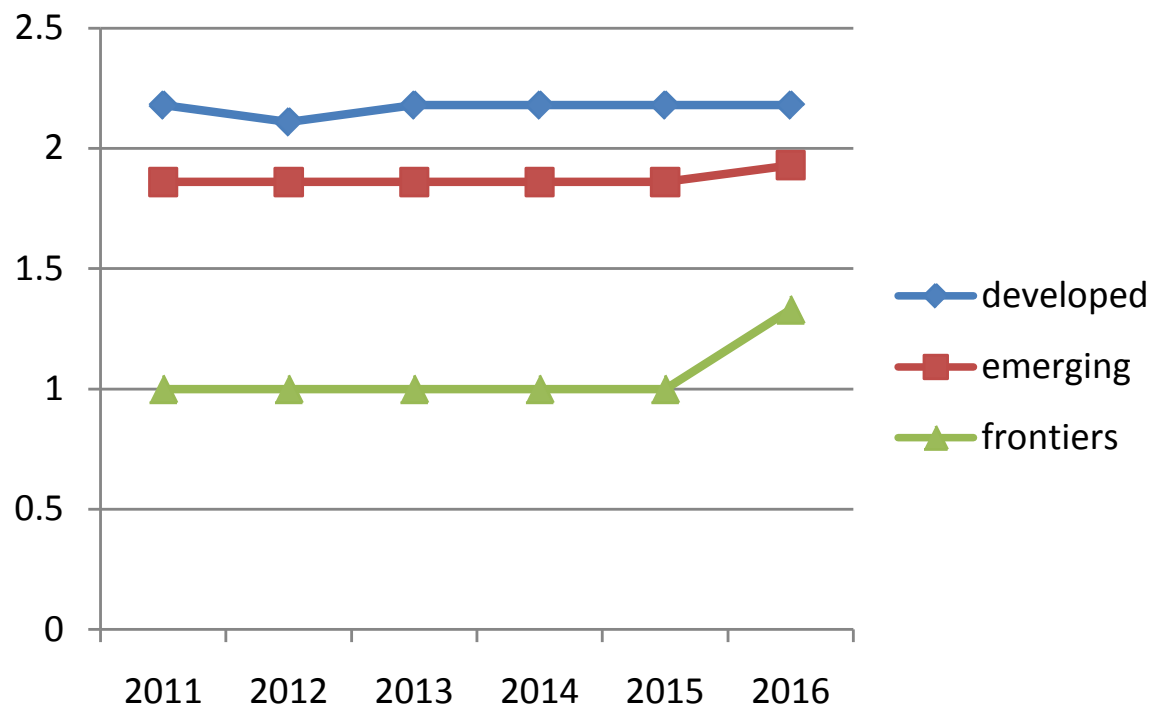

Figure 4. Procedural aspect trend. 
Table 5. Policy aspect.

\begin{tabular}{|c|c|c|c|c|c|c|}
\hline Country & 2011 & 2012 & 2013 & 2014 & 2015 & 2016 \\
\hline Canada & 3 & 3 & 3 & 2 & 2 & 2 \\
\hline USA & 3 & 3 & 3 & 3 & 3 & 3 \\
\hline Australia & 3 & 3 & 3 & 3 & 3 & 3 \\
\hline New Zealand & 3 & 3 & 3 & 3 & 3 & 3 \\
\hline Hong Kong & 1 & 1 & 1 & 1 & 1 & 1 \\
\hline Japan & 3 & 3 & 3 & 3 & 3 & 3 \\
\hline Singapore & 0.5 & 0.5 & 0.5 & 0.5 & 0.5 & 0.5 \\
\hline Israel & 2.5 & 2.5 & 2.5 & 2.5 & 2.5 & 2.5 \\
\hline Denmark & 2.5 & 2.5 & 2.5 & 2.5 & 2.5 & 2.5 \\
\hline Iceland & 3 & 3 & 3 & 3 & 3 & 3 \\
\hline Norway & 3 & 3 & 3 & 3 & 3 & 3 \\
\hline Sweden & 3 & 3 & 3 & 3 & 3 & 3 \\
\hline United Kingdom & 3 & 3 & 3 & 3 & 3 & 3 \\
\hline Switzerland & 1 & 1 & 1 & 1 & 1 & 2 \\
\hline Egypt & 2 & 2 & 2 & 2 & 2 & 2 \\
\hline South Africa & 2 & 2 & 2 & 2 & 2 & 2 \\
\hline Mexico & 2.5 & 2.5 & 2.5 & 2.5 & 2.5 & 2.5 \\
\hline Chile & 3 & 3 & 3 & 3 & 3 & 3 \\
\hline Korea & 3 & 3 & 3 & 3 & 3 & 3 \\
\hline India & 2.5 & 2.5 & 2.5 & 2.5 & 2.5 & 2.5 \\
\hline Indonesia & 1.5 & 1.5 & 1.5 & 1.5 & 1.5 & 1.5 \\
\hline Malaysia & 3 & 3 & 3 & 3 & 3 & 3 \\
\hline Philippines & 1.5 & 1.5 & 1.5 & 1.5 & 1.5 & 1.5 \\
\hline Thailand & 1.5 & 1.5 & 1.5 & 1.5 & 1.5 & 1.5 \\
\hline Saudi Arabia & 0 & 0 & 0 & 0 & 0 & 0 \\
\hline Turkey & 3 & 3 & 3 & 3 & 3 & 3 \\
\hline Hungary & 3 & 3 & 3 & 3 & 3 & 3 \\
\hline Russia & 2.5 & 2.5 & 2.5 & 2.5 & 2.5 & 3 \\
\hline Jamaica & 1 & 1 & 1 & 1 & 1 & 1 \\
\hline Argentina & 0.5 & 0.5 & 0.5 & 0.5 & 0.5 & 0.5 \\
\hline Jordan & 0 & 0 & 0 & 0 & 0 & 0 \\
\hline Romania & 2.5 & 2.5 & 2.5 & 2.5 & 2.5 & 2.5 \\
\hline Ukraine & 0 & 0 & 0 & 0 & 0 & 2.5 \\
\hline Croatia & 1.5 & 1.5 & 1.5 & 1.5 & 1.5 & 1.5 \\
\hline ECB & 2.5 & 2.5 & 2.5 & 2.5 & 3 & 3 \\
\hline
\end{tabular}


Finally, the operational aspect of monetary policy transparency refers to the achievement of the policy's targets and the analysis of the possible macroeconomic disturbances that occurred. The values of this aspect for each country are given in Table 6.

The high level of transparency in its operational aspect was reached in developed countries due to the necessity for explanations over the macroeconomic disturbances caused by the financial crisis. Central Banks in most developed countries had chosen to publish almost all data to which operational aspect refers. On the other hand, Central Banks in most emerging countries publish only short term forecasts about the policy's transmission process and a superficial evaluation of the policy's outcome in light of its macroeconomic objectives, but no explanations about achieved targets. For Central Banks in the frontier countries, their publishing policy significantly differs from country to country. For example, some of them prefer to publish full data about their control over the main operating instruments, but no forecasts for macroeconomic disturbances or evaluation of the policy meeting the target. Others prefer to publish short-term forecasts without giving explanations about their policy reaching the target. This aspect does not follow a common rule about data publication for the frontier countries. As it can be observed in Figure 6, an increase in the operational aspect is present in 2016.

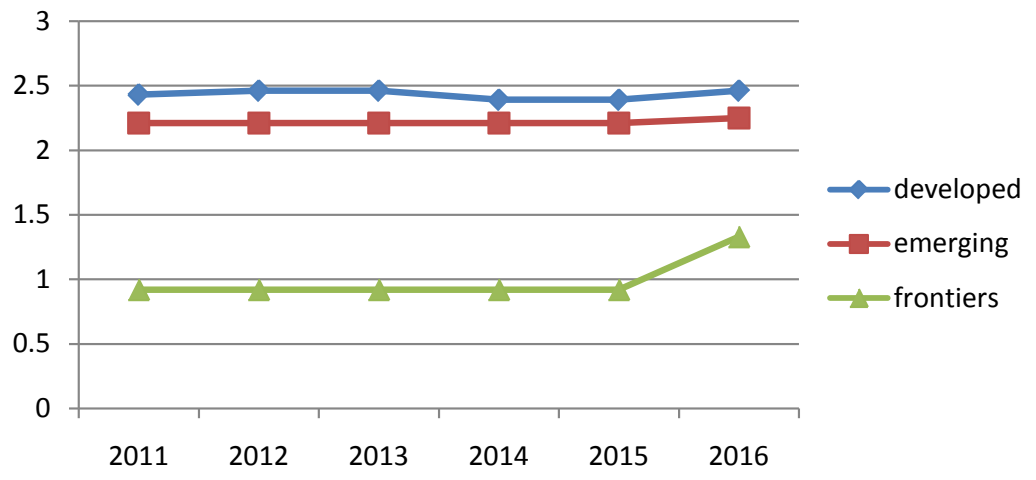

Figure 5. Policy aspect trend.

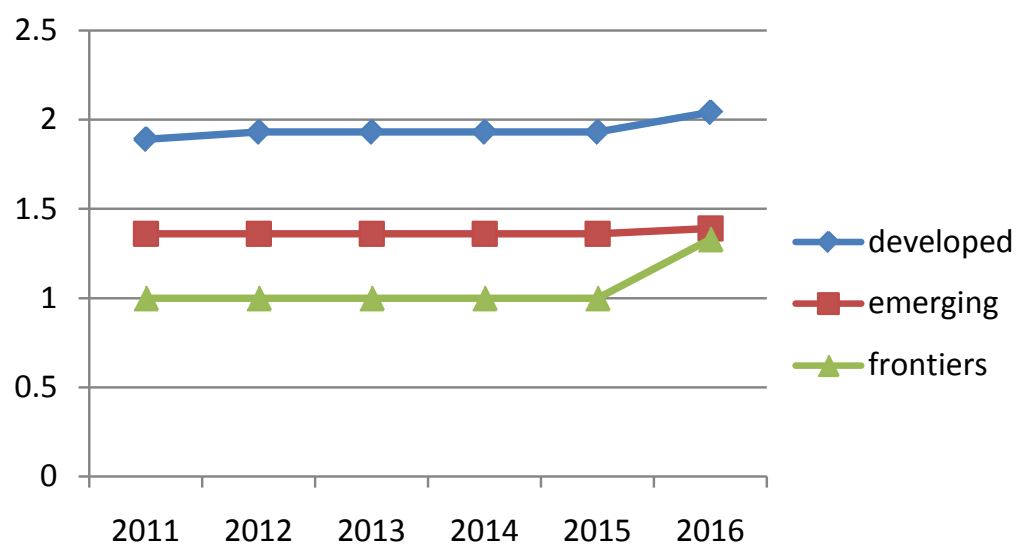

Figure 6. Operational aspect trend. 
Table 6. Operational aspect.

\begin{tabular}{|c|c|c|c|c|c|c|}
\hline Country & 2011 & 2012 & 2013 & 2014 & 2015 & 2016 \\
\hline Canada & 3 & 3 & 3 & 3 & 3 & 3 \\
\hline USA & 1 & 1 & 1 & 1 & 1 & 1.5 \\
\hline Australia & 2 & 2 & 2 & 2 & 2 & 2 \\
\hline New Zealand & 3 & 3 & 3 & 3 & 3 & 3 \\
\hline Hong Kong & 1 & 1 & 1 & 1 & 1 & 1 \\
\hline Japan & 2 & 2 & 2 & 2 & 2 & 2 \\
\hline Singapore & 0.5 & 0.5 & 0.5 & 0.5 & 0.5 & 0.5 \\
\hline Israel & 2 & 2 & 2 & 2 & 2 & 2 \\
\hline Denmark & 1 & 1 & 1 & 1 & 1 & 1 \\
\hline Iceland & 3 & 3 & 3 & 3 & 3 & 3 \\
\hline Norway & 1 & 1.5 & 1.5 & 1.5 & 1.5 & 1.5 \\
\hline Sweden & 3 & 3 & 3 & 3 & 3 & 3 \\
\hline United Kingdom & 2.5 & 2.5 & 2.5 & 2.5 & 2.5 & 2.5 \\
\hline Switzerland & 1.5 & 1.5 & 1.5 & 1.5 & 1.5 & 2.5 \\
\hline Egypt & 1.5 & 1.5 & 1.5 & 1.5 & 1.5 & 1.5 \\
\hline South Africa & 1.5 & 1.5 & 1.5 & 1.5 & 1.5 & 1.5 \\
\hline Mexico & 1.5 & 1.5 & 1.5 & 1.5 & 1.5 & 1.5 \\
\hline Chile & 1.5 & 1.5 & 1.5 & 1.5 & 1.5 & 1.5 \\
\hline Korea & 2 & 2 & 2 & 2 & 2 & 2 \\
\hline India & 1 & 1 & 1 & 1 & 1 & 1 \\
\hline Indonesia & 1.5 & 1.5 & 1.5 & 1.5 & 1.5 & 1.5 \\
\hline Malaysia & 1 & 1 & 1 & 1 & 1 & 1 \\
\hline Philippines & 1 & 1 & 1 & 1 & 1 & 1 \\
\hline Thailand & 1.5 & 1.5 & 1.5 & 1.5 & 1.5 & 1.5 \\
\hline Saudi Arabia & 0 & 0 & 0 & 0 & 0 & 0 \\
\hline Turkey & 1.5 & 1.5 & 1.5 & 1.5 & 1.5 & 1.5 \\
\hline Hungary & 2.5 & 2.5 & 2.5 & 2.5 & 2.5 & 2.5 \\
\hline Russia & 1 & 1 & 1 & 1 & 1 & 1.5 \\
\hline Jamaica & 2 & 2 & 2 & 2 & 2 & 2 \\
\hline Argentina & 2 & 2 & 2 & 2 & 2 & 2 \\
\hline Jordan & 0 & 0 & 0 & 0 & 0 & 0 \\
\hline Romania & 1 & 1 & 1 & 1 & 1 & 1 \\
\hline Ukraine & 0 & 0 & 0 & 0 & 0 & 1.5 \\
\hline Croatia & 1 & 1 & 1 & 1 & 1 & 1.5 \\
\hline $\mathrm{ECB}$ & 1.5 & 1.5 & 1.5 & 1.5 & 2 & 2 \\
\hline
\end{tabular}




\section{Conclusion}

In this study, we investigated the evolution of the transparency index over the period 2011-2016. By examining the transparency index of 34 economies, we observe that there is a positive trend in the progress of the index as a whole, which is mainly attributed to emerging and frontier economies' Central Banks. We also notice that the economic aspect of transparency has improved the most. This is due to an increase in the communication of projections about macroeconomic and financial variables by Central Banks, in their effort to anchor the private sector's inflation expectations. Overall, it seems that the upward trend in monetary policy transparency will continue in the future, because more and more Central Banks decide to pursue an explicit price-stability objective and recognize the importance of information disclosure for economic agents.

\section{Acknowledgements}

We would like to thank all those Central Banks that responded to our feedback questionnaire and helped us to complete as correctly as possible our work.

\section{References}

[1] Eijffinger, S. and Geraats, P. (2006) How Transparent Are Central Banks? European Journal of Political Economy, 22, 1-22. https://doi.org/10.1016/j.ejpoleco.2005.09.013

[2] Liu, M.-H., Margaritis, D. and Tourani-Rad, A. (2008) Monetary Policy Transparency and Pass-Through of Retail Interest Rates. Journal of Banking and Finance, 32, 501-511. https://doi.org/10.1016/j.jbankfin.2007.06.012

[3] Papadamou, S., Sidiropoulos, M. and Spyromitros, E. (2015) Central Bank Transparency and the Interest Rate Channel: Evidence from Emerging Economies. Economic Modelling, 48, 167-174. https://doi.org/10.1016/j.econmod.2014.10.016

[4] Geraats, P.M. (2002) Central Bank Transparency. Economic Journal, 112, 532-565. https://doi.org/10.1111/1468-0297.00082

[5] Demertzis, M. and Hughes-Hallet, A. (2007) Central Bank Transparency in Theory and Practice. Journal of Macroeconomics, 29, 760-789.

https://doi.org/10.1016/j.jmacro.2005.06.002

[6] Hussain, S.M. (2011) Simultaneous Monetary Policy Announcements and International Stock Markets Response: An Intradayanalysis. Journal of Banking \& Finance, 35, 752-764. https://doi.org/10.1016/j.jbankfin.2010.09.002

[7] Dai, M. and Spyromitros, E. (2012) Inflation Contract, Central Bank Transparency and Model Uncertainty. Economic Modelling, 29, 2371-2381.

https://doi.org/10.1016/j.econmod.2012.06.021

[8] Papadamou, S., Sidiropoulos, M. and Spyromitros, E. (2014) Does Central Bank Transparency Affect Stock Market Volatility? Journal of International Financial Markets, Institutions and Money, 31, 362-377. https://doi.org/10.1016/j.intfin.2014.05.002

[9] Papadamou, S., Sidiropoulos, M. and Spyromitros, E. (2017) Interest Rate Dynamic Effect on Stock Returns and Central Bank Transparency: Evidence from Emerging Markets. Research in International Business and Finance, 39, 951-962. https://doi.org/10.1016/j.ribaf.2016.01.020 
[10] Dai, M. (2016) Static and Dynamic Effects of Central Bank Transparency. Bulletin of Economic Research, 68, 55-78. https://doi.org/10.1111/boer.12031

[11] Weber, C. (2017) The Unemployment Effect of Central Bank Transparency. BGPE Discussion Paper (No. 172).

[12] Fry, M., Julius, D., Mahadeva, L., Roger, S. and Sterne G. (2000) Key Issues in the Choice of Monetary Policy Framework. In: Mahadeva, L. and Sterne, G., Eds., Monetary Policy Frameworks in a Global Context, Routledge, London, 1-216.

[13] Siklos, P.L. (2002) The Changing Face of Central Banking: Evolutionary Trends Since World War II. Cambridge University Press, Cambridge. https://doi.org/10.1017/CBO9780511606427

[14] Siklos, P.L. (2011) Central Bank Transparency: Another Look. Applied Economics Letters, 18, 929-933. https://doi.org/10.1080/13504851.2010.515199

[15] Crowe, C. and Meade, E. (2008) Central Bank Independence and Transparency: Evolution and Effectiveness. European Journal of Political Economy, 24, 763-777. https://doi.org/10.1016/j.ejpoleco.2008.06.004

[16] Papadamou, S. (2013) Market Anticipation of Monetary Policy Actions and Interest Rate Transmission to US Treasury Market Rates. Economic Modelling, 33, 545-551. https://doi.org/10.1016/j.econmod.2013.04.050

[17] Dincer, N.N. and Eichengreen, B. (2014) Central Bank Transparency and Independence: Updates and New Measures. International Journal of Central Banking, 10 189-259.

[18] Van der Cruijsen, C. and Demertzis, M. (2007) The Impact of Central Bank Transparency on Inflation Expectations. European Journal of Political Economy, 23, 51-66. https://doi.org/10.1016/j.ejpoleco.2006.09.009 